\title{
New development of spinel bonded chrome-free basic brick
}

\author{
S. Ghanbarnezhad ${ }^{1 \star}$, A. Nemati ${ }^{1,2}$, M. Bavand-Vandchali ${ }^{1}$ and R. Naghizadeh ${ }^{3}$ \\ ${ }^{1}$ Department of Materials Engineering, Science and Research Branch, Islamic Azad University, Tehran, Iran. \\ ${ }^{2}$ Department of Materials Engineering, Sharif University of Technology, Tehran, Iran. \\ ${ }^{3}$ Department of Metallurgy and Material Engineering, Iran University of Science and Technology (IUST), Tehran, Iran.
}

Accepted 3 January, 2013

\begin{abstract}
Due to the water solubility of Magnesia-Chrome bricks, the hexavalent chromium ion $\left(\mathrm{Cr}^{6+}\right)$ present in these bricks has been reported for use from rotary cement kilns. Magnesia-Chrome bricks are being replaced with chrome-free brick mainly of magnesia-spinel type. So, the aim of the present study is to develop new Cr-free brick with the addition of $\mathrm{TiO}_{2}$. All of properties such as bulk density, apparent porosity, cold crashing strength, modulus of rupture strength, hot modulus of rupture strength and refractoriness under load are measured on the basis of Japanese Industrial Standards (JIS). Also, the coating test and corrosion resistance were carried out against raw cement meal. Microstructural analysis and phase identification had been done by scanning electron microscopy, which is equipped with an energy dispersive X-ray analysis (SEM/EDS), also, mineral phases present in the sample were determined by using X-Ray diffraction. According to the result spinel phases such as magnesiaaluminate and magnesia-titanate as a main phase is formed as well as other lateral phases which have promoted the properties and microstructure.
\end{abstract}

Key words: Cr-free brick, magnesia-titanate, magnesia -aluminate, coating, corrosion.

\section{INTRODUCTION}

Magnesia-chrome bricks have been standard lining for the hot kiln zones since $\sim 1940$. Their properties are mainly determined by the use of refractory grade chrome ores (Bartha and Klischat, 1999). The bonding of the bricks strongly influences the performance of a magnesia-chrome refractory lining. In the so-called direct bonded magnesia bricks, the grains are bonded tightly to the surrounding matrix. In general, the presence of alkalis in oxidizing atmosphere can degenerate the chrome-ore of magnesia-chrome bricks. The reaction is accompanied by the formation of toxic hexavalent chromate (Bray, 1985; Driscoll, 1994).

Recently, an increase in environmental concerns has pushed each company to strive for zero-emission status and/or to achieve the environmental ISO-certification.

\footnotetext{
*Corresponding author. E-mail: S.ghanbarnezhad@yahoo.com.
}

For cement kilns refractory, $\mathrm{MgO}$-over saturated spinel are preferred as their eutectic of $2135^{\circ} \mathrm{C}$ is much higher than the burning temperature of the cement $\left(1450^{\circ} \mathrm{C}\right)$. Because of different thermal expansion coefficients between spinel and the magnesia matrix a microcrack system exists in the brick, which results in a decrease of the elasticity.

For this reason one of the methods for obtaining magnesia spinel bricks is the addition of alumina and titania $\left(\mathrm{TiO}_{2}\right)$ to a magnesia composition and the spinel is formed during the brick firing by an in-situ reaction (Komatsu et al., 1999; Bartha and Klischat, 1994). Magnesia-spinel bricks are high thermal shock resistance (not sensitive against reducing /oxidizing conditions, but are attacked by thermal overload (Makino et al., 2004). On the other hand, spinel forms low-melting phases with the result of a premature wear. To overcome this problem, by latest development, effort is directed at increasing use of $\mathrm{MgO}-\mathrm{TiO}_{2}$ products (Lodha et al., 2011). 
Table 1. Chemical compositions of raw materials.

\begin{tabular}{lcccccccc}
\hline Oxide raw material (\%) & $\mathbf{M g O}$ & $\mathbf{C a O}$ & $\mathrm{Al}_{2} \mathbf{O}_{3}$ & $\mathrm{Fe}_{2} \mathbf{O}_{3}$ & $\mathrm{SiO}_{2}$ & $\mathrm{TiO}_{2}$ & L.O.I & $\mathbf{B . D}\left(\mathbf{g} \cdot \mathbf{C m}{ }^{-3}\right)$ \\
\hline China magnesia & 97.20 & 1.20 & 0.20 & 0.32 & 0.70 & & 0.38 & 3.28 \\
Czech magnesia & 89.90 & 2.95 & 0.10 & 7.00 & 0.80 & & 0.00 & 3.32 \\
Tabular alumina & & & 99.50 & & & & & 3.55 \\
Titanium oxide & & & & & & 99.50 & & 4.25 \\
\hline
\end{tabular}

Table 2. Experimental compositions

\begin{tabular}{lccc}
\hline Batch & Weight $\% \mathrm{MgO}$ & Weight $\% \mathrm{Al}_{2} \mathrm{O}_{3}$ & Weight $\% \mathrm{TiO}_{2}$ \\
\hline Without additive & 80 & 20 & - \\
With additive & 80 & 5 & 15 \\
\hline
\end{tabular}

Particle size distribution was $1-4 \mathrm{~mm},<1 \mathrm{~mm}$ and $<75 \mu \mathrm{m}$.

Table 3. the bricks properties.

\begin{tabular}{|c|c|c|c|c|c|c|}
\hline Component & $\begin{array}{c}\text { Bulk } \\
\text { Density } \\
\left(\mathrm{g} \cdot \mathrm{cm}^{3}\right)\end{array}$ & $\begin{array}{l}\text { Apparent } \\
\text { prosity } \\
(\%)\end{array}$ & $\begin{array}{l}\text { Cold crashing } \\
\text { strength } \\
\left(\text { kgf.cm }^{-3}\right) \\
\end{array}$ & $\begin{array}{l}\text { Modulus of } \\
\text { rupture strength } \\
\left(\mathrm{kgf} . \mathrm{cm}^{-2}\right)\end{array}$ & $\begin{array}{c}\text { Hot Modulus of } \\
\text { rupture strength } \\
1000-1400^{\circ} \mathrm{C}\left(\mathrm{kgf} . \mathrm{cm}^{-2}\right)\end{array}$ & $\begin{array}{c}\begin{array}{c}\text { Refractoriness } \\
\text { under load }\end{array} \\
\mathrm{T}_{0}=1610 \mathrm{~T}_{2}=1720^{\circ} \mathrm{C}\end{array}$ \\
\hline $\mathrm{MgO}-\mathrm{Al}_{2} \mathrm{O}_{3}-\mathrm{TiO}_{2}$ & 3.1 & 15.4 & 505 & 59.5 & $73-32.5$ & $<2$ \\
\hline $\mathrm{MgO}-\mathrm{Al}_{2} \mathrm{O}_{3}$ & 2.76 & 21 & 256 & 23 & $38-11$ & $\geq 2$ \\
\hline
\end{tabular}

\section{EXPERIMENTAL PROCEDURE}

\section{Materials tested}

The experimental compositions were designed as the sintered magnesia (China and $\mathrm{Czech}$ Industries), $\mathrm{Al}_{2} \mathrm{O}_{3}$ (Alcoa company) and $\mathrm{TiO}_{2}$ (Merck company) which are shown in Tables 1 and 2 as the chemical and experimental compositions of raw materials. These compositions were mixed in a laboratory blender for $15 \mathrm{~min}$ for homogenisation using $\mathrm{MgCl}_{2}$ as the binder. Then, the mixes pressed to form brick $(198 \times 200 \mathrm{~mm})$ pressed at $1.2 \mathrm{T.cm}-{ }^{2}$, dried at $110^{\circ} \mathrm{C}$ for $24 \mathrm{~h}$ before firing at $1410^{\circ} \mathrm{C}$ for $52 \mathrm{~h}$ in a gas kiln.

\section{Experimental apparatus and method}

The bulk densities of dense compact (low porosity) were measured by employing the water immersion technique based on the Archimedes principle.

Properties such as cold crashing strength, modulus of rupture strength, hot modulus of rupture strength in 1000 and $1400^{\circ} \mathrm{C}$ and refractoriness under load, were measured on the basis of Japanese Industrial Standards (JIS). These apparatuses were from ECO companies in Japan and those models in sequence were JAN1992, TSA-522 and TSAR-612. The microstructure polished was investigated under SEM, Vega//Tescan. For mineral phases distinguishing $\mathrm{X}$-ray diffraction from a Phillips company (PW 3710) were used.

The chemical composition of the raw cement clinker was done by X-ray Fluorescence from a Philips company (PW 1606).

\section{RESULTS AND DISCUSSION}

On refractory system with ceramic bonding such as magnesia-spinel refractory, density and porosity are dependent on particle size distribution, density of each component, even, sintering process and reactions which are accompanied by volume expansions.

Also, strength strongly depends on the types of acting forces or stresses and the presence of imperfections. Ceramic-based materials are relatively brittle under tensile and bending stresses (Carniglia and Barna, 1992). As shown in Table 3, brick properties with additive have improved, when compared to the sample without additive.

According to reaction: (1) with the dissolution of titanium in magnesium lattice, of valence variations between $\mathrm{Ti}^{4+}$ and $\mathrm{Mg}^{2+}$, vacancy cation will be created. This vacancy leads to rise in diffusion coefficient, and sintering becomes easier.

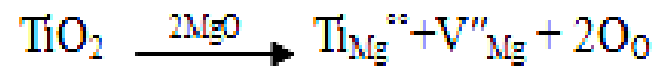

As shown in Figures 1 and 2, when using an electron microscope by backscatter electron (SEM/BSE) and microchemical analysis by energy dispersive X-ray analysis (SEM/EDS) to analyze the samples without 

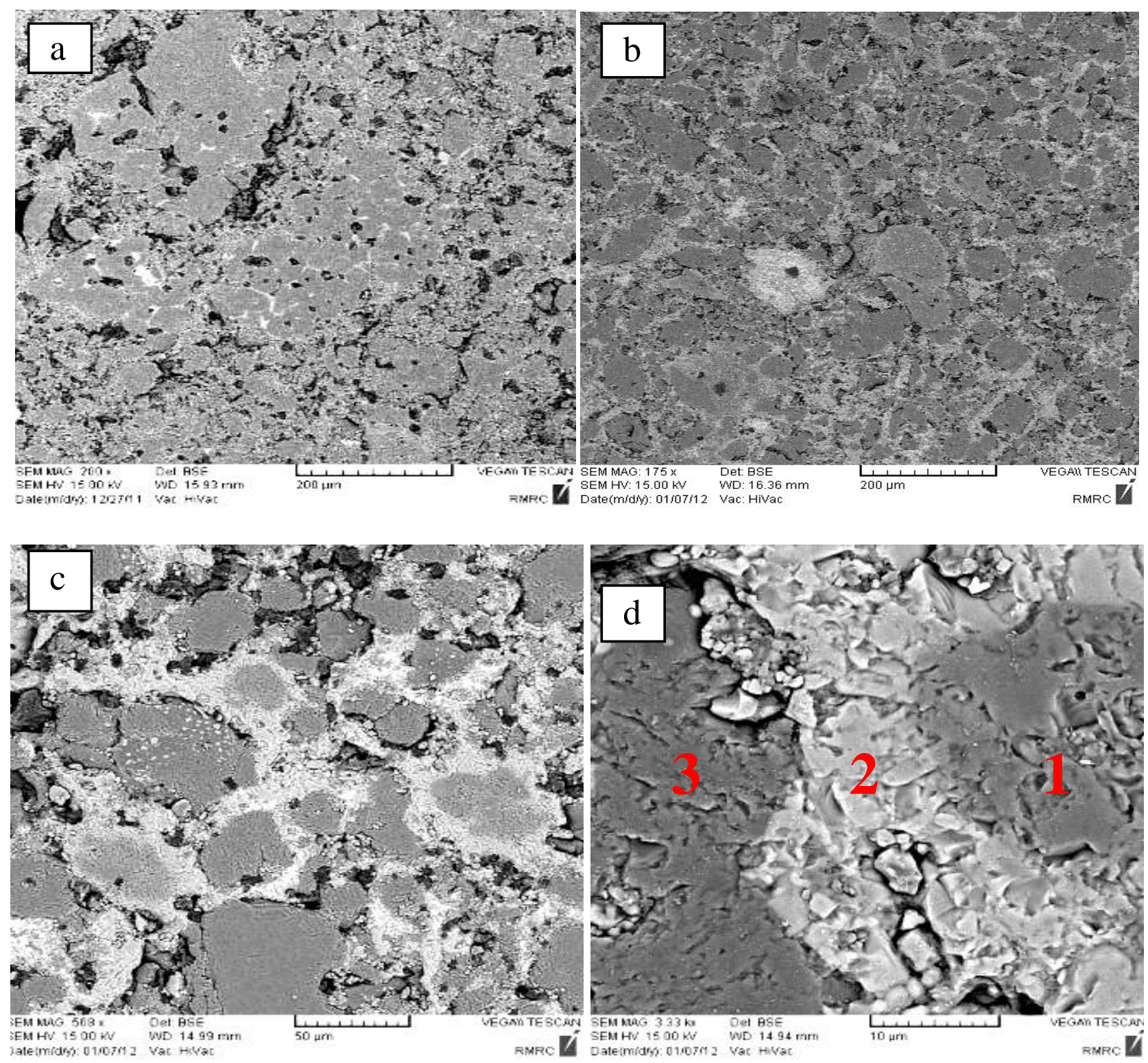

Figure 1. SEM of the samples: (a) without additive, (b), (c) and (d) with additive.

additive and by its, it is observed that, magnesia-titanate phase develop a strong bond between in-situ magnesiaspinel as well as magnesia aggregates. The reactions: (2), (3) and (4), shows the formation of solid solution, that this causes the increase in strength.

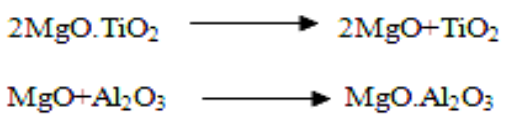

$2 \mathrm{MgO} \cdot \mathrm{TiO}_{2}+\mathrm{MgO} \cdot \mathrm{Al}_{2} \mathrm{O}_{3} \longrightarrow\left[2 \mathrm{MgO} \cdot \mathrm{TiO}_{2}-\mathrm{MgO} \cdot \mathrm{Al}_{2} \mathrm{O}_{3}\right]_{\mathrm{ss}}$

s.s: solid solution

Probably, the sintering was stated above $1000^{\circ} \mathrm{C}$ and done in liquid phases, because $\mathrm{CaO}$ and $\mathrm{Fe}_{2} \mathrm{O}_{3}$ are in magnesia. Figure 3 shows the X-ray diffraction patterns of sample with and without additive after sintering in $1410^{\circ} \mathrm{C}$. According to the reactions: (5) and (6), $\mathrm{TiO}_{2}$ reacts with $\mathrm{CaO}$, and $\mathrm{Fe}_{2} \mathrm{O}_{3}$, and calcium-iron titanate will be formed.

$$
\begin{aligned}
& \mathrm{TiO}_{2} \stackrel{2 \mathrm{CaO}}{\longrightarrow} \mathrm{Ti}_{\mathrm{Ca}}{ }^{s s}+\mathrm{V}^{\prime \prime} \mathrm{Ca}+2 \mathrm{O} \text { 。 } \\
& \mathrm{Ca}^{2+}\left(\mathrm{Fe}^{3+}\right)_{2} \mathrm{O}_{4} \longrightarrow \mathrm{VO}^{2 s}+\mathrm{Fe}_{\mathrm{Ca}}{ }^{2}+\mathrm{V}_{\mathrm{Fe}}{ }^{\prime \prime \prime}+1 / 2 \mathrm{O}_{2} \\
& +\mathrm{Ca}+\mathrm{Fe}_{\mathrm{Fe}}{ }^{*}+3 \mathrm{O}^{*} \\
& \mathrm{x} \mathrm{Ca}{ }^{2+}\left[\mathrm{Fe}^{3+}\right]_{2} \mathrm{O}_{4}+(1-\mathrm{x}) \mathrm{Ca}^{2+}\left[\mathrm{Ca}^{2+} \mathrm{Ti}^{4+}\right] \mathrm{O}_{4} \longrightarrow \\
& \mathrm{Ca}^{2+}\left[\begin{array}{llll}
\mathrm{Fe}^{3+}{ }_{2 \mathrm{x}} \mathrm{Ca}^{2+}{ }_{1-\mathrm{x}} & \mathrm{Ti}^{4+}{ }_{1-\mathrm{z}}
\end{array}\right] \mathrm{O}_{4} \\
& 0 \leq \mathrm{x} \leq 1
\end{aligned}
$$



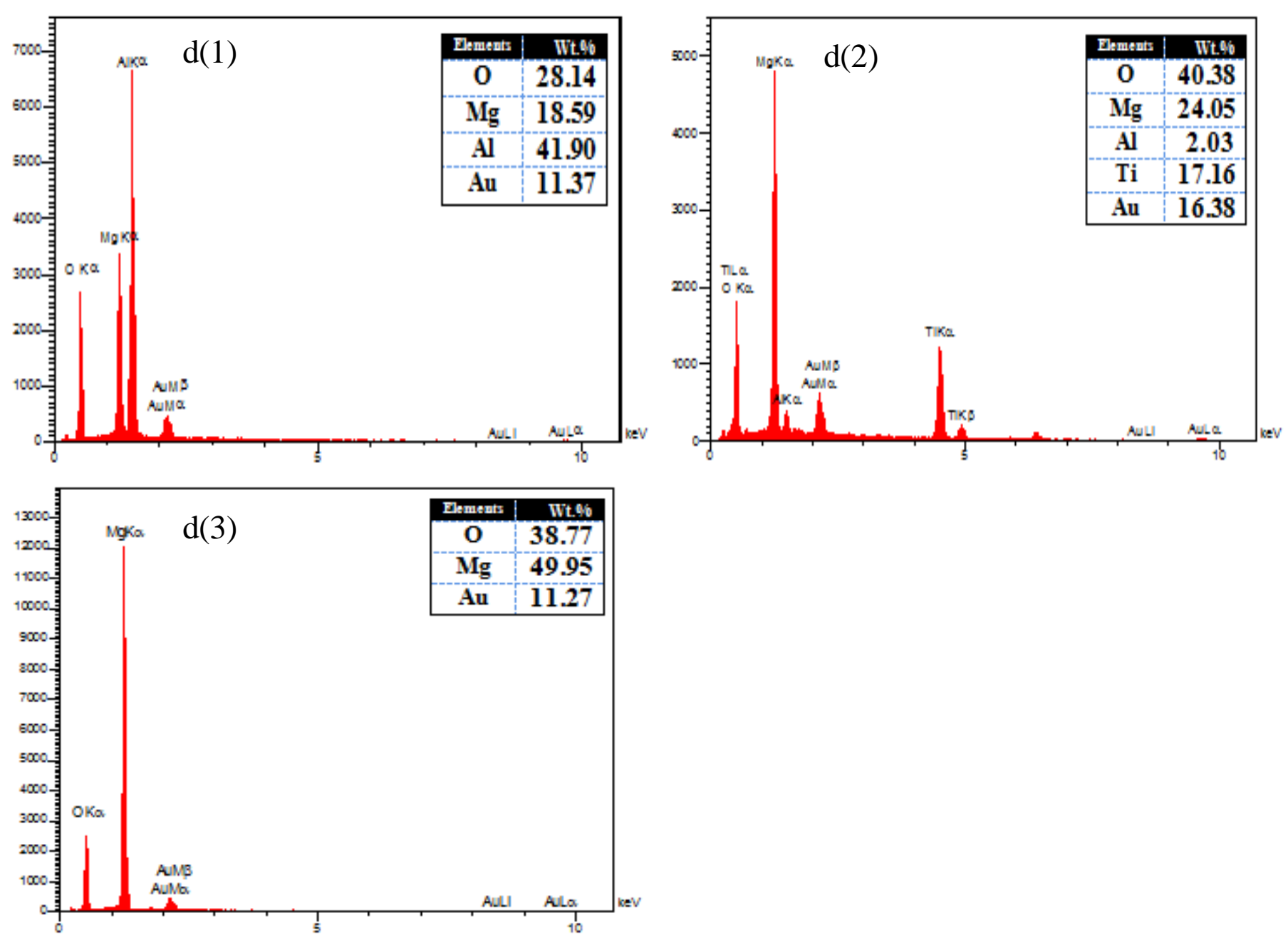

Figure 2. Microchemical analysis by energy dispersive X-ray analysis (SEM/EDS) of sample with $\mathrm{TiO}_{2}$.

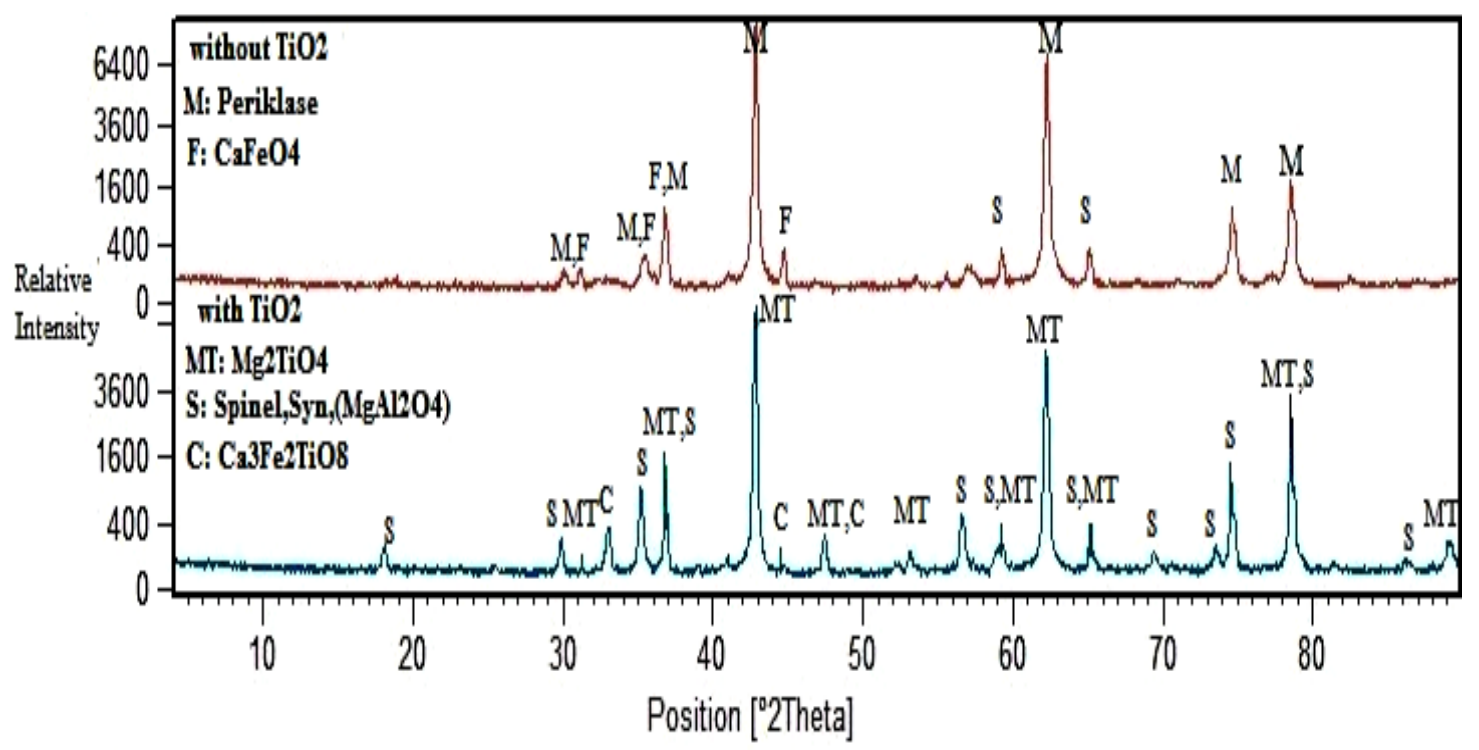

Figure 3. X-ray diffraction patterns from samples after sintering in $1410^{\circ} \mathrm{C} ; \mathrm{MT}: \mathrm{Mg}_{2} \mathrm{TiO}_{4}$; S: Spinel(MA); C: $\mathrm{Ca}_{3} \mathrm{Fe}_{2} \mathrm{TiO}_{8}$ and $\mathrm{F}: \mathrm{CaFeO}_{4}$ 
Table 4. The chemical composition of the raw cement clinker.

\begin{tabular}{lcccccccccccc}
\hline Oxide (\%) & $\mathrm{SiO}_{2}$ & $\mathrm{Al}_{2} \mathrm{O}_{3}$ & $\mathrm{Fe}_{2} \mathrm{O}_{3}(\mathrm{t})$ & $\mathrm{CaO}$ & $\mathrm{Na}_{2} \mathrm{O}$ & $\mathrm{K}_{2} \mathrm{O}$ & $\mathbf{M g O}$ & $\mathrm{TiO}_{2}$ & $\mathbf{M n O}$ & $\mathbf{P}_{2} \mathrm{O}_{5}$ & $\mathbf{S O}_{3}$ & $\mathrm{~L} . \mathbf{O} . \mathbf{I}$ \\
\hline Clinker & 14.95 & 2.62 & 2.77 & 41.57 & 0.29 & 0.51 & 1.65 & 0.157 & 0.072 & 0.080 & 0.223 & 34.68 \\
\hline
\end{tabular}
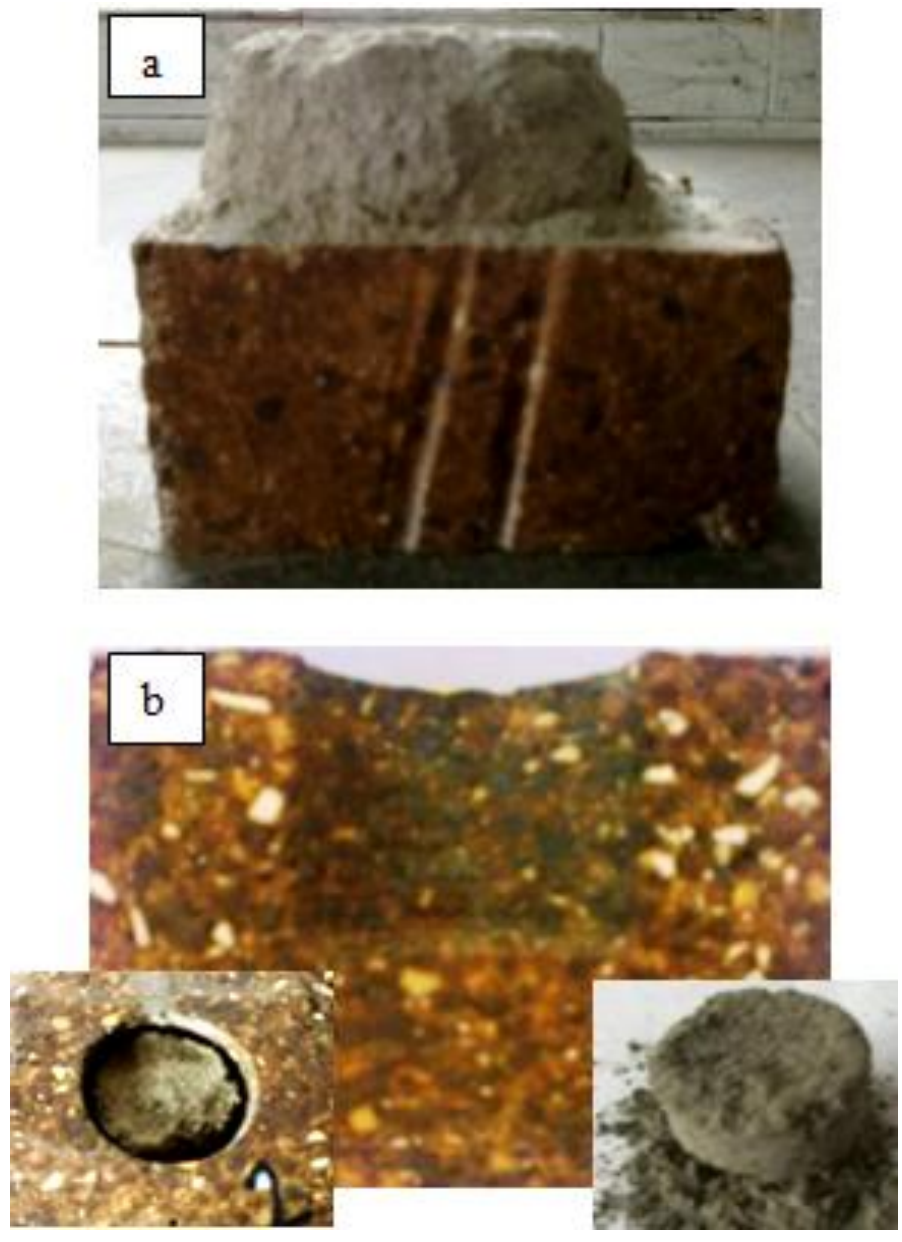

Figure 4. (a) Coating (b) corrosion resistance images of the brick.

Because, the reaction of magnesia, alumina and titania form spinel and is accompanied by volume expansion, microcracks are frequently resulted in the microstructure and these have a network stresses, and at elevated temperatures these are released. Thus, strength and stability increases. On the other hands, due to the changes in ingredient morphology at high temperature, $\mathrm{HMOR}$ reduced in $1400^{\circ} \mathrm{C}$ compared with $1000^{\circ} \mathrm{C}$. Moreover, in $1400^{\circ} \mathrm{C}$, low melting point phases are formed.

\section{Coating and corrosion study}

For coating experiment, the brick was coated with disk form of raw cement clinker and sintered in 1400 to $1450^{\circ} \mathrm{C}$ for six hours and for corrosion resistance, the brick was cut in crucible forms and filled by raw cement clinker. Then, put at 1400 to $1450^{\circ} \mathrm{C}$ for six hours in lab kiln as shown in Table 4 showing the chemical composition of the raw cement clinker.

Figure 4 shows the images of the brick after coating and corrosion test. In between the magnesia-spinel bricks and coating zone, $\beta \mathrm{C}_{2} \mathrm{~S}$ rich phase is formed and this phase at $725^{\circ} \mathrm{C}$ transmitted to $\mathrm{YC}_{2} \mathrm{~S}$ and this reaction is accompanied by a $10 \%$ volume expansion. Thus, these phenomena have caused the downfall of coating that dusting also caused (Sarkar et al., 2003).

Because $\mathrm{CaO}$ in the cement clinker reacts with $\mathrm{TiO}_{2}$ in the brick and formed calcium -titanate phase, the phase increased the linkage potency between brick and coating. Already as mentioned, sintering of calcia proceeded with the progress of densification induced by particle growth similar to that of magnesia. As a factor of this densification, the formation of solid solution by diffusion of titanium into calcia, identical with the magnesia, and the formation of low temperature melting compounds, namely calcium-titanate $\left(\mathrm{CaO} . \mathrm{TiO}_{2}, 3 \mathrm{CaO} .2 \mathrm{TiO}_{2}\right)$ is considered to take place. However, as for the formation of a solid solution, the difference of ionic radius is large, namely, $\mathrm{Ca}^{2+} 0.099$ and $\mathrm{Ti}^{4+} 0.068 \mathrm{~nm}$, so there seems to be little possibility for the formation of solid solution of titanium. Furthermore, with respect to their melting points, the relative sintering temperature of calcia $\left(\mathrm{m}\right.$. p. $\left.2570^{\circ} \mathrm{C}\right)$ was higher than that of magnesia $\left(\mathrm{m}\right.$. p. $\left.2800^{\circ} \mathrm{C}\right)$ (Ghanbarnezhad et al., 2012; Ozeki et al., 2001), so the titanium was more effective for the coating.

This feature is attributed to the fact that the solid solution formation is more difficult in calcia and the melting temperature of calcium-titanate is higher than magnesium-titanate. Magnesia-spinel bricks reacts with the cement material.

These bricks, which naturally contain $\mathrm{Al}_{2} \mathrm{O}_{3}$ from compounds of the $\mathrm{CaO}-\mathrm{Al}_{2} \mathrm{O}_{3}-\mathrm{SiO}_{2}$ system: these cause substantial corrosion of the bricks because of their relatively low melting points and the low viscosity of the produced liquid phase. Therefore, $\mathrm{TiO}_{2}$ will be added to improve the corrosion resistance of these sorts of bricks (Ozeki et al., 2001; Kajita et al., 2000). As another approach $\mathrm{TiO}_{2}$ additives were supposed to accelerate the growth of the coating layer on hot face of the brick, as it is expected that such additives form $\mathrm{CaO}-\mathrm{TiO}_{2}$ compounds of rather high melting points.

It is reported that these additives effectively contribute to the increasing of the high temperature strength of the 
bricks by forming spinel, forming minerals of rather high melting points and accelerating the sintering of the brick.

\section{Conclusions}

The results showed that with the addition of $\mathrm{TiO}_{2}$, reactions between $\mathrm{MgO}-\mathrm{TiO}_{2}$ has reinforced the microstructure of brick.

Meanwhile, $\mathrm{TiO}_{2}$ improved all properties as well as the coating ability and corrosion resistance of the bricks that exhibit a good thermal stability and an excellent chemical resistance against clinker raw meal. As a result this brick has qualities needed in the hot zone of rotary cement kilns as well as lime, iron, glass and steel industry.

\section{REFERENCES}

Bartha P, Klischat HJ (1994). Classification of magnesia bricks in rotary cement kilns according to specification and serviceability. ZKG Int. 47(10):277-280.

Bartha P, Klischat HJ (1999). Present state of the refractory lining for cement kilns. CN-Refractories. 6(3):31-38.
Bray DJ (1985). Toxicity of chromium compounds formed in refractories. Ceram. Bull. 64(7):1012-1016.

Carniglia SC, Barna GL (1992). Handbook Industrial Refractories. pp. 288-290.

Driscoll MO (1994). Price temper steel market promise. Ind. Min. 324:35-49.

Ghanbarnezhad S, Bavand-Vandchali M, Nemati A, Naghizadeh R (2012). Coating ability and corrosion resistance of basic brick with $\mathrm{TiO}_{2}$ for rotary cement kilns. JOMB. J. 1(1):62-65.

Kajita Y, Ozeki F, Honda T (2000). The present and future of chromefree linings for rotary cement kilns. Jap. J. 20(4):266-270.

Komatsu H, Arai M, Ukawa S (1999). Current and future status of chrome-free bricks for rotary cement kilns. Taikabutsu Overseas 19(4):3-9.

Lodha R, Oprea C, Troczynski T, Oprea G (2011). Magnesia-rich chromium-free spinel-bonded basic refractories. UB Ceram, Department of Material Engineering of British Columbia, Advances in Refractories V-The Michel Rigaud Symposium.

Makino H Obana T, Tsuchinari A (2004). The application of ${\mathrm{MgO}-\mathrm{TiO}_{2-}}^{-}$ $\mathrm{Al}_{2} \mathrm{O}_{3}$ aggregates for Cr-free refractories. Jap. J. 24(4):259.

Ozeki F, Kajita Y, Honda T, Ota Sh (2001). Chrome-free basic for cement rotary kilns. Jap. J. 21(2):78-84.

Sarkar R, Ghosh A, Das SK (2003). Reaction sintered magnesia rich magnesium aluminate spinel: Affect of alumina reactivity. Ceram. Int. 29:407-411. 